Gevel Sebagai Karakter Bangunan Kolonial Dengan Fungsi Rumah Tinggal Di Kota Tegal

\title{
GEVEL SEBAGAI KARAKTER BANGUNAN KOLONIAL DENGAN FUNGSI RUMAH TINGGAL DI KOTA TEGAL (STUDI KASUS JALAN GAJAH MADA KOTA TEGAL)
}

\author{
Nuthqy Fariz*), Agung Budi Sardjono*), Titien Woro Murtini*). \\ Departemen Arsitektur Magister Arsitektur Universitas Diponegoro Semarang
}

\begin{abstract}
Abstrak
Sebagai kota yang berada di pesisir jawa bisa dikatakan Tegal telah mengalami beberapa perkembangan dan perubahan pada masa kolonial sampai dengan sekarang, baik dari segi manusianya, budaya ataupun peniggalannya. Kota tegal merupakan satu dari beberapa kota di pesisir pantai utara yang dijajah atau dikuasai oleh pemerintah belanda pada masa penjajahan dahulu.

Bangunan peninggalan di tegal yang pertama yaitu gedung berau atau NIS Tegal yang masih bertahan sampai sekarang, bangunan tersebut dirancang oleh arsitek belanda yaitu Henricus Maclaine Pont, bukan gedung berau saja tetapi juga ada Stasiun Kereta Api Tegal yang masih difungsikan sampai sekarang. Dari beberapa bangunan kolonial yang dibangun pada masa itu banyak dari perumahan atau rumah rumah belanda yang meniru bentuk dan motif bangunan kolonial yang sudah dibangun terlebih dahulu.

Dari bangunan yang ditiru yaitu bangunan DPRD Kota Tegal yang memiliki langam arsitektur eropa brgaya romawi dengan ciri bentuk kolom yang besar dan mempunyai gevel pada bagian depan bangunan. Dengan gevel yang semakin banyak digunakan pada bangunan di Kota Tegal tidak lepas dari rumah rumah yang menggunakan gevel sebagai penanda bangunan yang sangat manis pada masa itu.

Gevel merupaka bagian dari atap dengan yang dibuat untuk menaungi bagian teras pad bangunan gevel biasanya menyerupai bentuk segitiga dan bentuk persegi atau bujur sangkart, gevel banyak digunakan pada rumah-rumah di kawasan cagar budaya Kota Tegal yaitu di kelurahan mangkukusuman, kelurahan panggung, kelurahan tegalsari .

Pada penelitian ini menggunakan metode penelitian kualitatif deskriptif dengan mencari tahu dilapangan rumah-rumah kolonial yang menggunakan gevel, sehingga bisa dkategorikan gevel menjadi karakter dari kawasan tersebut.

Hasil dari penelitian ini yaitu mengetahui bahwa gevel menjadi bentuk karakter yang ada pada sepanjang jalan gajah mada Kota Tegal.
\end{abstract}

Keywords: Gevel; Karakter; Rumah; Bangunan Kolonial

\section{Latar Belakang}

Tegal merupakan salah satu dari beberapa kota yang berada di pesisir pantai utara atau yang biasa di sebut dengan pantura, dengan perkembangan dan pertumbuhan masyarakat dan perkonomiannnya maka kota tegal merupakan jalur yang biasa dilalui para pedagang baik dari timur jawa maupun dari barat jawa. Moda tranportasi terus berkembang dari mulai tranportasi darat sampai dengan laut, dari kapal laut sampai dengan bus dan kereta api. Kereta api memang sudah sejak zaman kolonial sebagai angkutan yang paling banyak digunakan setelah kapal laut. Setelah pemerintah belanda dahulu membangun jalan dan juga membangun jalur kereta api dari jakarta sampai ke surabaya. Kota tegal tidak pernah terlepas dari transit yang biasa dilakukan pada zaman dahulu. Stasiun kereta api tegal yang dibangun oleh belanda pada tahun 1918 ini sampai sekarang masih bisa dimanfaatkan sebagai stasiun kereta api besar Kota Tegal. Dan bangunan selain sasiun kereta api ada bangunan gedung SCS milik KAI yang juga sebagai bangunan cagar budaya, ada gedung DPRD yang mempunyai langgam arsitektur romawi dengan kolom yang besar juga masih banyak lagi.

Sesuai dengan UU cagar budaya ada beberapa bangunan di Kota Tegal masuk dalam bangunan cagar budaya, diantaranya ada pendopo Kota Tegal, Gedung DPRD Kota Tegal, Kantor Pos, Markas TNI AL Tegal, Stasiun Tegal, Gedung NIS, dan masih banyak beberapa bangunan yang masih bertahan samapi sekarang.

Menurut Ching (1979) fasad bangunan merupakan "Komponen visual yang menjadi objek transformasi dan modifikasi dari fasade bangunan dapat diamati dengan membuat klasifikasi melalui prinsip-prinsip gagasan formatif yang menekankan pada geometri, simetri, kontras, ritme, proporsi dan skala “ 
Menurut Krier (2001) fasad bangunan merupakan suatu kesatuan tersendiri dengan kemampuan untuk mengekspresikan dirinya sendiri. Namun demikian, komposisi suatu fasade terdiri dari penstrukturan di satu sisi dan penataan pada sisi lainnya.

Bangunan rumah yang ada di kota tegal termasuk bangunan rumah kolonial beberapa sudah menjadi tanah rata ada yang masih aktif dan difungsikan dari dahulu sampai sekarang.

\section{Metode Penelitian}

Penelitian ini menggunakan penelitian kualitatif deskriptif rasionalistik. Menurut Muhajir (1996), dengan menggunakan metode ini maka menuntut untuk lebih banyak terjun langsung ke lapangan dengan metode pengumpulan data dengan metode pengamatan (observasi) dan metode survey dan wawancara. Tujuan penelitian ini adalah untuk mengetahui bahwa gevel sebagai karakter bangunan kolonial dengan fungsi rumah tinggal di kawasan cagar budaya kota tegal. Dengan mencari data dilapangan langsung survey dan mencari narasumber yang bisa diwawancarai sebagai bahan untuk analisa.

\section{Lokasi Penelitian}

Kota Tegal sebagai salah satu daerah otonom di Provinsi Jawa Tengah yang terletak 109008' sampai 109o10' garis bujur timur dan 6o50' sampai 6o53' garis lintang selatan. Letak geografis Kota Tegal sangat strategis karena berada di pertigaan jalur Kota besar Purwokerto- Tegal- Jakarta dan Semarang- TegalJakarta. Batas- batas Wilayah Kota Tegal diantaranya adalah : Sebelah Utara : Laut Jawa Sebelah Timur : Kabupaten Tegal Sebelah Selatan : Kabupaten Tegal Sebelah Barat : Kabupaten Brebes

Berdasarkan laporan tahunan Survei Pertanian (SPVA) yang dilakukan oleh BPS, luas wilayah Kota Tegal adalah 39,68 km2. Luas tersebut sekitar 0,11\% dari luas Propinsi Jawa Tengah. Secara administrasi Kota Tegal dibagi menjadi 4 kecamatan dengan 27 Kelurahan, dengan wilayah terluas adalah Kecamatan Tegal barat sebesar 15,13 km2 disusul Kecamatan Margadana seluas 11,76 km2, Kecamatan Tegal Selatan 6,43 km2 dan Kecamatan Tegal Timur seluas $6,36 \mathrm{~km} 2$.

Menurut RJMD (Rencana Jangka Menengah Daerah) Kota Tegal pada bagian kawasan cagar budaya ditentukan bagian cagar budaya pada kelurahan panggung kecamatan Tegal Timur, kelurahan mangkukusuman Kecamatan Tegal Timur, dan kelurahan tegalsari Kecamatan Tegal Barat. Lokasi penelitian terletak di jalan gajah mada kelurahan tegalsari kecamatan Tegal Barat sehingga kawasan ini sudah masuk kawasan cagar budaya.
Benda cagar budaya adalah benda buatan manusia, bergerak atau tidak bergerak yang berupa kesatuan atau kelompok, atau bagian-bagian atau sisa-sisanya, yang berumur sekurang-kurangnya 50 (lima puluh) tahun, atau mewakili masa gaya yang khas dan mewakili masa gaya sekurang-kurangnya 50 (lima puluh) tahun, serta dianggap mempunyai nilai penting bagi sejarah, ilmu pengetahuan, dan kebudayaan; dan benda alam yang dianggap mempunyai nilai penting bagi sejarah, ilmu pengetahuan, dan kebudayaan (UU No. 5/1992 Pasal 1).

Menurut undang undang rebuplik indonesia yang menatur tentang bangunan onservasi dan bangunan cagar budaya sudah ada pada UU No 10 Tahun 2011 yang sebelumnya telah diperbaharui dari UU Tahun 1992. Cagar Budaya adalah warisan budaya bersifat kebendaan berupa Benda Cagar Budaya, Bangunan Cagar Budaya, Struktur Cagar Budaya, Situs Cagar Budaya, dan Kawasan Cagar Budaya di darat dan/atau di air yang perlu dilestarikan keberadaannya karena memiliki nilai penting bagi sejarah, ilmu pengetahuan, pendidikan, agama, dan/atau kebudayaan melalui proses penetapan.

\section{Gaya Arsitektur Indische Empire}

Arsitektur Indische Empire adalah gaya yang berkembang di abad ke-19 di Hindia Belanda. Gaya arsitektur dipopulerkan oleh Gubernur Jenderal HW Daendles (1808-1811). Ciri-ciri gaya arsitektur Indische Empire, sebagai berikut

(Hadinoto, 2010: 149):

a. denah bangunan berbentuk simetri.

b. terdapat ruang tengah yang terdiri dari kamar tidur. c. Kamar Central secara langsung berkaitan dengan teras depan dan belakang (Voor Galerij dan Achter) d. Teras biasanya sangat luas dan pada salah satu ujung ada deretan Yunani atau kolom gaya Romawi (Doric, Ionic, Corinthian).

e. Dapur, kamar mandi/WC, penyimpanan dan area layanan lainnya adalah bagian yang terpisah dari bangunan utama dan terletak di bagian belakang.

f. Kadang-kadang di samping bangunan utama ada paviliun, yang digunakan sebagai kamar tidur tamu.

g. Rumah skala besar, biasanya terletak di sebidang tanah dengan taman depan dan sisi belakang.

\section{Gaya Arsitektur Transisi (1890-1915)}

Arsitektur transisi plagiarisme Romatik gaya arsitektur Eropa (Handinoto,2010:125). Bangunan gaya arsitektur transisi sebagian besar

dirancang oleh inspektur bangunan yang bekerja ganda pada departemen pengembangan pemerintah Belanda (Handinoto 2010: 128).

\section{Kajian Pustaka}


Menurut Handinoto (2010: 1414) gaya arsitektur transisi tidak hanya bangunan ala militer, tetapi juga gaya bangunan umum atau pemerintah lainnya yang dibangun pada abad ke-19 sampai awal abad ke-20, seperti: bangunan

kantor PTT (Pos, Telegraaf en Telefoon) di Jogyakarta (dirancang pada tahun 1910 dan dibangun pada tahun 1912);

Kantor pos Medan (1909), dan markas "Nillmij" Jakarta (1909).

\section{Gaya Arsitektur Indo-Eropah (1920-1930)}

Arsitektur Indo-Eropah diarahkan pada bangunan yang memiliki bentuk campuran arsitektur Nusantara dan arsitektur modern disesuaikan iklim, bahan bangunan dan teknologi yang berkembang pada saat itu (Handinoto 2010:86). Gaya arsitektur Indo-Eropa yang didirikan oleh arsitek Henri Maclaine Pont, Thomas Karsten, dan Hendrik Petrus Berlage. Institut Teknologi Bandung adalah bangunan menganut gaya arsitektur Indo-Eropa.

Menurut Handinoto dalam bukunya (1996) tentang ciri ciri bangunan kolonial sebagai berikut :

1. Gable/gevel, berada pada bagian tampak bangunan, berbentuk segitiga yang mengikuti bentukan atap.

2. Tower/Menara, variasi bentuknya beragam, mulai dari bulat, kotak atau segi empat ramping, segi enam, atau bentuk-bentuk geometris lainnya,

3. Dormer/Cerobong asap semu, berfungsi untuk penghawaan dan pencahayaan. Di tempat asalnya, Belanda, dormer biasanya menjulang tinggi dan digunakan sebagai ruang atau cerobong asap untuk perapian.

4. Tympannon/Tadah angin, merupakan lambing masa prakristen yang diwujudkan dalam bentuk pohon hayat, kepala kuda, atau roda matahari.

5. Ballustrade, ballustrade adalah pagar yang biasanya terbuat dari beton cor yang digunakan sebagai pagar pembatas balkon, atau dek bangunan;

6. Bouvenlicht/Lubang ventilasi, bouvenlicht adalah bukaan pada bagian wajah bangunan yang berfungsi untuk memenuhi kebutuhan kesehatan dan kenyamanan termal.

7. Windwijzer (Penunjuk angin), merupakan ornament yang diletakkan di atas nok atap. Ornamen ini berfungsi sebagai penunjuk arah angin;

8. Nok Acroterie (Hiasan puncak atap), terletak di bagian puncak atap. Ornamen ini dulunya dipakai pada rumah-rumah petani di Belanda, dan terbuat dari daun alang-alang.

9. Geveltoppen (Hiasan kemuncak atap depan); Voorschot, berbentuk segitiga dan terletak di bagian depan rumah.

Gevel yang ada pada bagian rumah yang berarsitektur kolonial yang ada dikawasan cagar budaya sebagai bagian dari karakter yang ada pada bangunan dengan fungsi rumah tinggal

\section{Data}

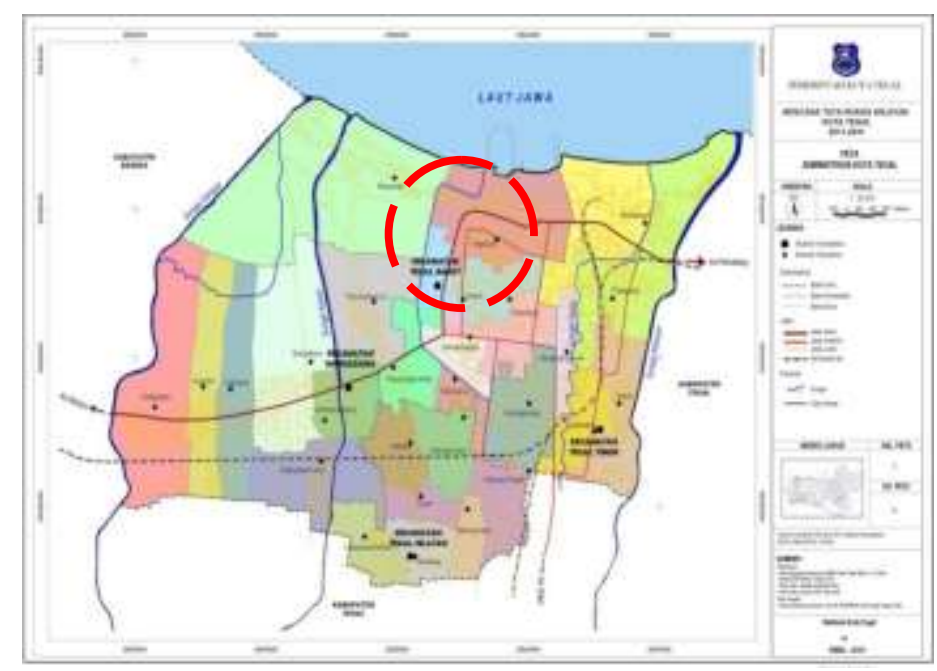

Data yang didapat dilapangan berada pada kelurahan tegalsari kecamatan tegal barat Kota Tegal. Ada 20 sampel dari total 30 bangunan dengan fungsi sebagai rumah tinggal.

\begin{tabular}{|l|c|c|}
\hline No & Objek Penelitian & Fungsi Bangunan \\
\hline 1. & Rumah Tinggal & $\begin{array}{c}\text { Bangunan Rumah Tinggal } \\
\text { Alamat jalan gajah mada } \\
\text { Kota Tegal }\end{array}$ \\
\hline & & \\
\hline
\end{tabular}




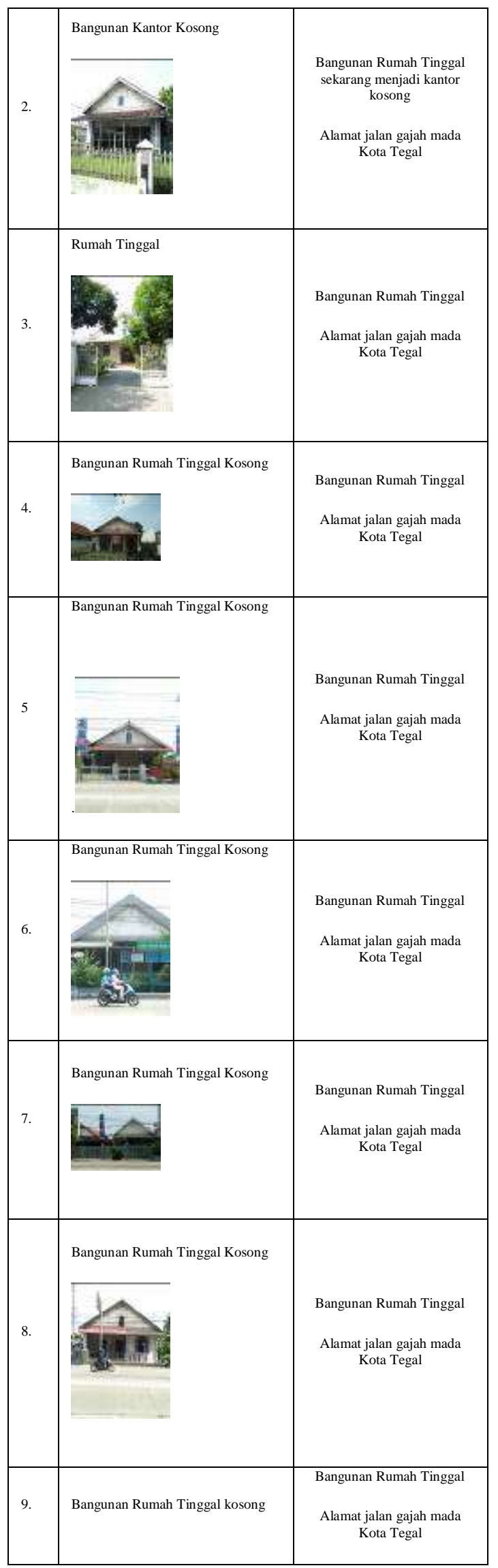

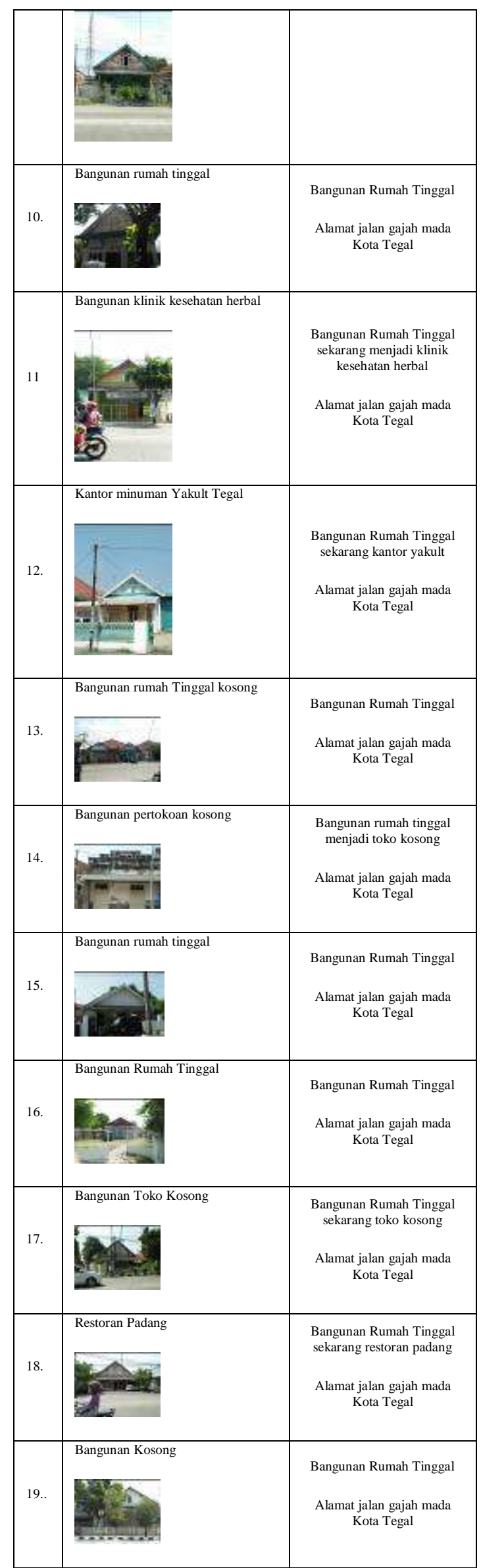




\begin{tabular}{|l|l|c|}
\hline 20. & $\begin{array}{c}\text { Bangunan Rumah Tinggal } \\
\text { Alamat jalan gajah mada } \\
\text { Kota Tegal }\end{array}$ \\
\hline 21. & Bangunan Rumah Tinggal & $\begin{array}{c}\text { Bangunan Rumah Tinggal } \\
\text { Alamat jalan gajah mada } \\
\text { Kota Tegal }\end{array}$ \\
\hline 22. & Bangunan Rumah Tinggal & $\begin{array}{c}\text { Bangunan Rumah Tinggal } \\
\text { Alamat jalan gajah mada } \\
\text { Kota Tegal }\end{array}$ \\
\hline
\end{tabular}

\section{Analisa}

Dari data yang telah peneliti survey maka bisa diketahui ada skitar 22 sampel ,ada beberapa bagian gavel yang tidak berbentuk segitiga tetapi berbentuk persegi bisa dikatakan gevel yang mirip dengan tympanon, pada tahap analisa ini peneliti akan melihat dan mendata apakah benar dari 22 bangunan tersebut mempunyai gevel.

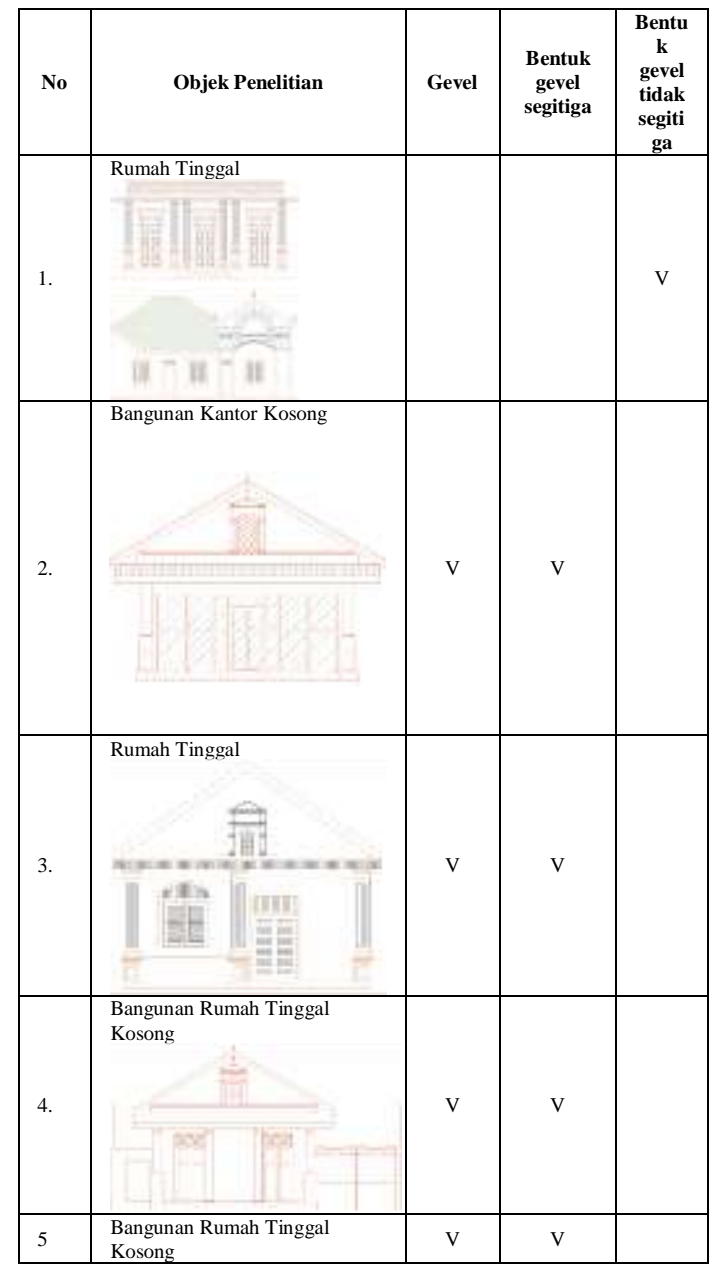

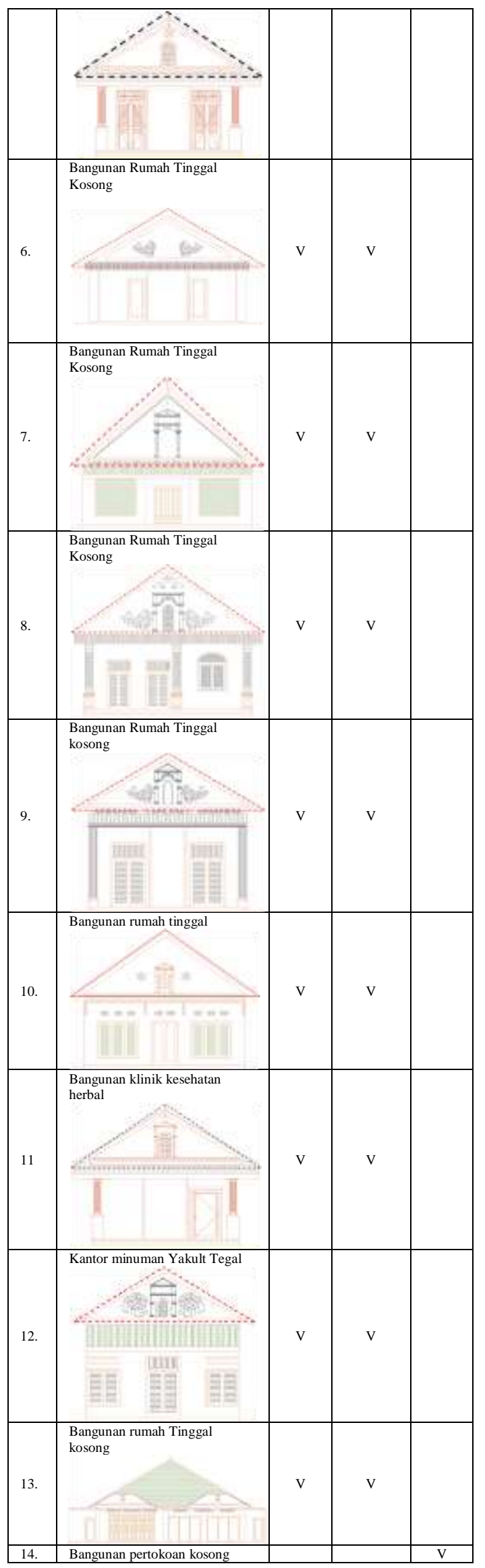




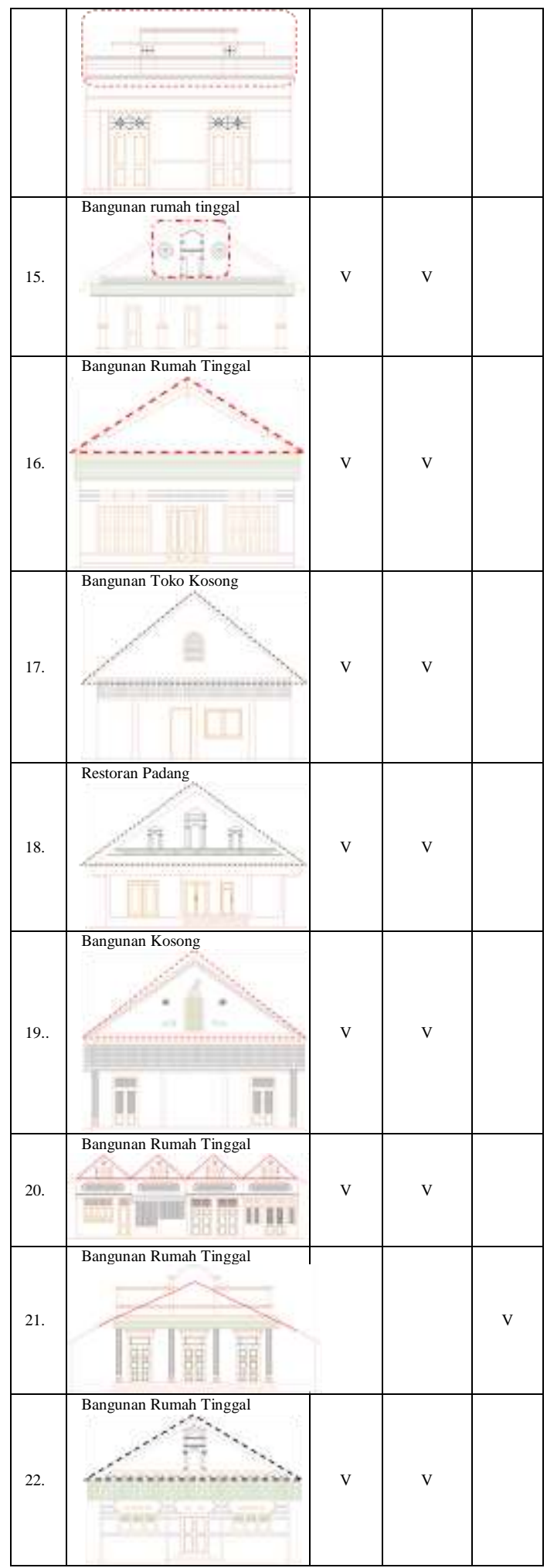

Dari 22 bangunan yang telah dianalisa ada 3 bangunan yang memang mempunyai gevel tapi tidak berbentuk segitiga atau bisa dikatakan itu tympanon yang hampir mirip dengan gevel.
Bentuk dan ukuran gavel hampir mirip satu dengan yang lainnya dan bentuk ornamennya juga mirip atau bisa dikatakan sama persis.

\section{Kesimpulan}

Dari analisa diatas bisa diambil kesimpulan bahwa hampir dari sepanjang jalan gajah mada Kota Tegal bangunan kolonial dengan fungsi rumah tinggal hampir semua memiliki gevel pada rumahnya. Dalam handinoto (2010) bahwa ciri dari bangunan kolonial yaitu adanya gevel / gable. Dari 22 bangunan hanya 19 yang mempunyai gevel dan yang 3 dengan tympanon yang sekilas mirip dengan gevel.

Bisa dikatakan bahwa karakter bangunan kolonial dengan fungsi rumah tinggal di jalan gajahmada Kota Tegal ini memiliki karakter adanya gevel atau bentuk atap segitiga yang ada di depan bangunan.

\section{Daftar Pustaka}

Berry, Wendell. 1980. Good Neighbors, Building Next to History: Design Guidelines Handbook. State Historical of Colorado. Colorado.

DK. Ching. 2000. Arsitektur bentuk ruang dan tatanan. Edisi ketiga. Jakarta. Erlangga.

Handinoto. 1996. Perkembangan Kota dan Arsitektur Kolonial Belanda di Surabaya 1870-1940. Diterbitkan atas Kerja Sama Lembaga Penelitian dan Pengabdian Kepada Masyarakat Universitas Kristen Petra Surabaya dan Penerbit Andi. Yogyakarta: Andi Offset.

Hadinoto. 2010. Arsitektur dan Kota-kota di Jawa. pada Masa Kolonial. Graha Ilmu. Yogyakarta.

Krier, Rob. 2001. Komposisi Arsitektur. Terjemahan Effendi Setiadharma. Jakarta: Erlangga

Mulyadi, L \& G. Sukowiyono. (2014). Kajian Bangunan Bersejarah di Kota Malang sebagai Pusaka Kota (Urban Heritage) Pendekatan Persepsi Masyarakat - Prosiding Temu Ilmiah IPLBI 2014. Bandung.

Ronald, Arya, 1997, Arsitektur Indo - Studi Kasus di Kota Padang, Medan dan Yogyakarta, Diskusi Ilmiah Arkeologi VIII Pelestarian dan pemanfaatan Bangunan Indis, Yogyakarta.

Sumalyo, Yulianto. 1993. Arsitektur Kolonial Belanda Di Indonesia. UGM Press. Yogyakarta.

Utomo, Tri Prasetyo. 2005. Tipologi dan Pelestarian Bangunan Bersejarah; Sebuah Pemahaman Melalui Proses Komunikasi. Jurnal Seni Rupa STSI Surakarta. 2 (1): 71-79.

Veronica A., Kumurur. 2015. Pengaruh Gaya Arsitektur Kolonial Belanda pada Bangunan Bersejarah di Kawasan Manado Kota Lama Prosiding Temu Ilmiah IPLBI 2015. 